\title{
Tóbiás László: Szakmai életutak az ifjúsági munkában: Szabó András
}

Szabó András 1951-ben született, és Lipótvárosban, a Parlament közelében lévő kis utcában, egy házmester-lakásban nőtt fel. Egy bátyja, és édesanyja korai halála után édesapja második házasságából született testvéröccse van. A Szemere utcai fiúiskolában kezdte meg tanulmányait, majd a Kossuth Zsuzsa Gimnázium és Ipari Szakközépiskolában nyomdai formakészítőként, szedőként végzett. Vásárhelyi Miklósné ${ }^{1}$ volt az osztályfönöke és a történelemtanára, aki bekapcsolta őt egy egyetemi felkészítő-tehetséggondozó programba. Szabó András mégsem jelentkezett egyetemre, inkább elhelyezkedett a szakmájában, és ejtőernyőzni kezdett. Úgy gondolta akkor, hogy felderítő katonatisztként lesz alkalma az ejtőernyőzésre. Amikor aztán kiderült számára, hogy ez olyan elitképzés, amely a céljához nem vezetheti el, elhagyta a katonai föiskolát, és visszatért nyomdász szakmájához. 1973-ban ugrott utoljára ejtőernyővel. A tiszti főiskolán pedagógia szakos is volt (mindenkinek kellett polgári szakot is végeznie). Diplomát később, 1980-ban szerzett pedagógia-népművelés szakokon, az Egri Ho Si Minh Tanárképző Főiskola budapesti kihelyezett tagozatán, a Tárogató utcában. Még 1972-ben kezdett járni a Kassák Klubba, bátyja invitálására, aki régebb óta látogatta a korszak emblematikus ifjúsági intézményét, ami formára művelődési ház volt, tartalmát tekintve pedig több progresszív kulturális vállalkozás és ezek alkotói kapcsolatainak bölcsője. Szabó András az 56 utáni politikai legitimáció-teremtés részének tekinti, hogy 1963 után a zsdanovi transzmissziós szovjet kultúrpolitikát meghaladóan megjelentek személyesebb társas kezdeményezések, közösségi és müvészeti kísérletek, ifjúsági klubok. Ebbe az irányzatba sorolja a Kassák Klubot, amelyet klubházként is definiál, ahol Nógrádi Gábor irányításával tulajdonképpen egymásra közvetlenül nem reflektáló kulturális és szabadidős tevékenységek is tudtak élni egymás mellett. Nógrádi Gábor támogatása is kellett ahhoz, hogy az ifjúsági klubok világát jobban megismerhette, de Itt egyebek mellett például Bujdosó Dezsőtől filmformanyelvet tanult, és azt, ahogyan elvitte a filmeket a külvárosi fiatalok közé. Önkéntes volt, aktív klubos, aki klubvezető-képzéseken fejlesztette az ismereteit. 1974-ben felkínálták neki a rákospalotai Kozák téren frissen elkészült ifjúsági klub vezetését. Vele egy időben kezdett a Frankovics Ifjúsági Házban vezetőként Péterfi Ferenc is, aki szintén a Kassák Klubból érkezett, ahol a zuglói diákklubot vezette éveken át. Sorsuk azóta is többször találkozott: 1977ben egyszerre kaptak Ifjúsági Díjat, és a 90-es évek közepétől, vagyis szinte a kezdetektől együtt rádióznak a Civil Rádióban. A Kozák téri Ifjúsági Ház vezetése számára az első, „nagy lélegzetü” önálló szakmai munka volt, ami addig csupa járatlan szakmai feladat felfedezésével is járt együtt. A Kozák téren dolgozott először cigány fiatalokkal, egyénekkel és közösséggel is. ${ }^{2}$ Ennek kapcsán is vált azon kevés magyar ifjúsági munkások egyikévé, akik publikálják is szakmai gondolataikat, eredményeiket. ${ }^{3}$ Abban az időben vált mély szakmai kapcsolattá és

\footnotetext{
${ }^{1}$ Nagy Imre 56-os kormánya sajtófőnökének, Vásárhelyi MIklósnak a felesége

${ }^{2}$ György E. (2017): A kisebbségi kulturális örökség létrehozásának kísérlete. A Rom Som cigányklub története (1972-1980) in Ignácz Ádám (szerk): Populáris zene és államhatalom. Rózsavölgyi és Társa - MTA BTK.

${ }^{3}$ Lásd Szabo Andras: „Amire meg emlékszem. Tapasztalataim a Kozák térről”. Studio. A Klubvezetői tevékenységről (1982)/2, 2. Szabó András (1992) Kapocs a Petőfi Csarnokban Ahogy egy ifjúságsegítő szervezet
} 
barátsággá Diósi Pálhoz füződő viszonya. „Mi csináltuk az ifjúsági munkát, Pali meg ledoktorált belőlünk." - szokta mondogatni. ${ }^{4}$ Szabó András révén a Kozák téren az ott megjelenő tizenévesek szocializációjának támogatására többféle müvészeti (afrozenei, képzőművészeti, báb, filmtörténeti) kezdeményezés indult, amelyek aztán számos továbbgondolásra is érdemes tapasztalatokat hoztak. 1977-ben elhagyta a Kozák teret, ahol leginkább a munka beindítása érdekelte, de már nem akarta azt ismételni, amit kitalált. A Csokonai Művelődési Házban pihent pár hónapot, amely időszakban közelebb került az amatőr színházi törekvésekhez. 1977 nyarán megismerkedhetett az amatőr színházi világszövetség magyarországi kurzusa szakmai termékeivel és részt vehetett azok hazai feldolgozásában. Ennek a hatására amatőr színházi csoportot hozott létre Pszínpad néven. Az Ikarus Mủvelődési Ház munkásmüvelődési előadója lett, de leginkább azért színházazott. Pszínpad társulatával 1977-80 között hozott létre produkciókat. Az Ikarus Mủvelődési Házban dolgozó Takács Ferenc Hurka Színházába olvasztotta be aztán saját csoportját. Egy milánói nemzetközi színházi mühely zárta végül ezt a tevékenységet, de a dramatikus eszközök beépültek a későbbi ifjúsági munkájába. 1980-ban elhagyta a közművelődés világát, és az Építésügyi Tájékoztató Központban lett irodalmi szerkesztő. Az épület még nem volt készen, amikor 1982-ben csatlakozott az Almássy téri Szabadidőközpont ${ }^{5}$ csapatához. Előbb a kerületi diákügyek, majd később a kortárs zenei és irodalmi események gondozása volt a feladata, Mezei Éva sárvári diákíró csoportját és táborait segítette, település- és divattörténeti projektet gondozott, majd ott az utolsó időszakban igazgatási osztályvezetőként a ház tényleges müködésének irányítása volt a feladata. Azoktól az évektől vesz részt a felsőoktatásban, és a Bárczi Gusztáv Gyógypedagógiai Főiskola Pszichopedagógiai Tanszéke tereptanára lett. 1986-ban a szerveződő Állami Ifjúsági és Sporthivatal Kulturális osztályára hívták. ${ }^{6}$ Az államigazgatásban töltött munkájában többféle tartalmi területen végzett feladatokat, például alternatív ifjúsági kezdeményezések támogatásával, modernizációs törekvések elősegítésével, a tehetséggondozás feladatainak erôsítésével, vagy akár a távoktatás indításával és hazai meghonosításával (aminek akkor egy elképzelés szerint döntő eszköze a korábban a szovjet hadsereg által használt tévéfrekvencia lehetett volna). Részt vett az ifjúsági letéti számlák létrehozásával kapcsolatos hivatali feladatokban is. Az államigazgatásból a megalakuló Nemzeti Gyermek- és Ifjúsági Alapítványhoz ment, ahol a vagyonkezelés körüli ügyeskedéseket látva gyorsan átigazolt az alapítvány szakmai stábjába. Ott dolgozott, amikor 1991-ben meghívták a Petőfi Csarnok pályázatába. Diósi Pál a Petőfi Csarnokot látogatók

elindult Család, gyermek, ifjúság 1992 3-4., Szabó András (1997) Kapocs - nyár - munka. Esély 1997/1; Szabó András (1998) Pillanatfelvétel a fiatalok számára reálisan elérhető egyszerübb munkahelyekröl. Esély 1998/2; Szabó András (1999) Kiszakadás vagy leszakadás. Esély 1999/4; Szabó András (2003): Kapocs-szisztéma. Módszertani összefoglaló az ifjúsági munka területéről. Család, gyermek, ifjúság 2003/4. Az interneten: a Kapocs Alapítvány honlapja, oldala a Facebookon és a Wikipédián, illetve a Civil Rádió Kapocs ifjúságsegítő magazinjának podcastja.

4 Diósi Pál: Csoportviszonyok és értékválasztások a Kozák-téri ifjúsági klubban. Budapest: Népművelési Propaganda Iroda Kozák tér, 1981.

5 Az Almássy téri Szabadidőközpontot 1983-ban nyitották meg Almássy téri Úttörö és Ifjúsági Ház, Szabadidőközpont néven, Budapesten, az Almássy tér 6. szám alatt.

${ }^{6}$ A kormányzati ifjúságpolitikai szervezeti átalakulások történetéhez lásd sorozatunk Wootsch Péterrel készített interjúját: Tóbiás László (2019) Szakmai életutak az ifjúsági munkában: Wootsch Péter - II. rész Párbeszéd 2019/3 https://doi.org/10.29376/parbeszed.2019.6/3/5 
körében felmérést végzett, és stratégiai javaslatokat adott az intézmény vezetőinek egy lehetséges ifjúságsegítő tevékenységrendszerhez. Az alapvetésként készített dokumentum képezte azt a várakozást, amelyre a pályázatba meghívott ifjúsági szakembereknek konkrét tevékenységi tervet kellett készíteniük. Szabó András koncepcióját választották ki megvalósításra. 1992 március 16-án lett a Hoci-nesze Alapítvány - a Kapocs Alapítvány jogelődje - munkatársa, bár a pályázatra meghívó a Petőfi Csarnok volt. (Azóta éli a közszolgáltatást nyújtó civil szervezetek munkatársainak nagyon is ismert egzisztenciális vezetőként a kollégákért is viselt felelősséggel terhelt - történetét. Szakmai életútja nagyobbik részében aztán megtapasztalhatta, hogy mi az alkotói önállóság és szabadság ára.) 1992-ben egy magánszerencse folytán az amerikai szövetségi kormányzat vendégeként bő hónapon át tanulmányozhatta a fiatalok felnőtté válásának jellemzőit és az ifjúsági munkát az USA-ban, bejárva az országot. A 40-50 megvalósítható, magyar kollégáknak bemutatott amerikai programból az éjszakai ping-pongozás terjedt el leginkább. A Kapocs munkájának kialakításakor erősen támaszkodott az itt szerzett tapasztalatokra, és azokra a tapasztalatokra is, amiket 1975-től a gödöllői művelödési ház felkérésére vagy tíz éven át szervezett önismereti jellegü sajátélmény táborok, majd csoportok vezetésével szerzett. A Kapocsban pszichopedagógia szakos, szociálpedagógia szakos és szociális munkás szakos egyetemisták tereptanára volt, később aztán ifjúságsegítő szakosoké is. Az ifjúságsegítő képzés létrejöttében aktívan közreműködött, mindvégig benne óraadó tanárként taníthatott, illetőleg részt vett a képzés fejlesztésében is. Az 1995-ös kezdetektől van müsora a Civil Rádióban. Eszköznek látta a rádiózást a Kapocsba járó fiatalok kommunikációja és önkifejezése fejlesztésére. Amikor 2006-ban a Kapocs a Józsefvárosba, a Mátyás térre költözött, teljesen kicserélődött a közönsége, leginkább a Kapocs Iroda környezetében élő és felnőtté váló meglehetősen elhanyagolt és elvadult tizenévesek vették birtokba. A Kapocs szervezete itt a korábban indított szakmai bázison egy alapvetően új tevékenységrendszerbe kezdett, amellyel nem csupán megkapaszkodott egy szakmai szempontból nagyon nehéz környezetben, hanem eredményesen sikerült egyengetnie számos fiatal látogatója rossz eséllyel induló életét. Az ottani látogatók számára is jó eszköznek tartotta a rádiózást, de nem a Civil Rádióban. Az ottani müsorát ifjúságszakmai magazinná alakította, a Kapocs tizenéves látogatóival pedig az éppen a közelben működő roma rádióban, a Rádió C-ben kezdett müsort. Országos ügyben két esetben kérték szakértői véleményét, a gyermekvédelmi törvény kidolgozásakor, illetve a gyerekszegénység elleni program, a Legyen jobb a gyerekeknek monitoring bizottságában. Utóbbi kapcsán kapott aztán később képzői felkéréseket is országszerte. 2005-ben felkérték Pesterzsébet gyerekjóléti szolgálata vezetésére. Ez kapóra jött, mert egy ideje már azon gondolkodott, hogy át kellene adnia a Kapocs vezetését és a szolgálatvezetővé válás elfogadható kilépési lehetőségnek látszott. Három hónap után azonban visszatért: nem kapott elég bizalmat, nem fogadta el szakmai értékei sérelmét és önállósága behatárolását. Másfél-két évig dolgozott még mellékállásban a távol lévő ifjúsági referens helyettesítőjeként Schiffer János főpolgármesterhelyettes mellett, akivel végül is nem nagyon vágtak egybe elképzeléseik. Demszky Gábor főpolgármestersége vége felé aztán megválasztották a Budapesti Ifjúsági Tanács elnökévé. A jól induló testület eljutott addig, hogy ifjúsági stratégiát kezdeményezhetett, amely révén tényleges és finanszírozható ifjúsági feladatrendszerre nyílt volna lehetősége. A folyamat azonban megrekedt, az új városvezetés gyakorlatilag elfordult attól, hogy ifjúsági feladatokat vállaljon. Azóta lemondani sem tud kinél, időnként kap a városházáról megkereséseket. Szabó 
András 2011 óta hivatalosan nyugdíjas, így legalább az ö fizetésére nem kell költeni az egyre gyérebb forrásokból. 2015. végén Józsefváros teljesen felhagyott a Kapocs támogatásával. A III. Kerületi Önkormányzat segítségével Kaszásdülőn lehetőséget kapott arra, hogy egy, a fiatalok foglalkoztatását segítő programja megmaradhasson. 2019-ben Szabó András úgy döntött, hogy a Kapocs megmaradt tevékenységeit átadja a Jövőbarát Egyesületnek, a Kapocs Alapítvány hivatalos müködésének felszámolását kezdeményezi. A Kapocsban és korábban szerzett szakmai tapasztalatai bázisán jelenleg, mint coach és ifjúsági szakértő heti két nap dolgozik megoldásközpontú tanácsadóként, segítve felnőtté válásukban kamaszokat és szüleiket. Vezeti a Civil Rádióban müsorait és a szerkesztőbizottságot. Hozzáfogott, hogy leírja azokat a tapasztalatokat és szakmai módszereket, amikkel találkozott, és amiket több mint 45 éve kezdett pályáján tanult és alkotott.

„Nehéz lenne mindenkit felsorolni, akitől tanultam. Nógrádi Gábortól Mérei tanár úron át Máté Lajoson át, aki annak idején a Népmüvelési Intézetben a Színházi osztályon dolgozott. Azt mondta: „,nagyon rossz rendezö vagyok, nem akarok ártani a színháznak, eljöttem a fiatalokhoz, az amatőrökhöz, hogy tölük tanuljak." Tényleg fantasztikus bácsi volt, nagyon kedveltem. Dévényi Éva pszichológus volt, talán pszichiáter is. Nagyon izgalmas szinházpszichológiai munkát végzett a Stúdió $K$ és egyebek mellett. Egy személyiség megragadásának lélektani folyamatában segített, például a Stúdió K Woyczeck elöadásához. Rengeteget tanultam arról, hogy a színész hogyan tudja belülröl kifelé felépiteni vagy ellenkezöleg: kívülröl belülre eljuttatni a figurát. Ez sok szempontból azért érdekes, mert amivel én foglalkozom - a fiatalok felnötté válása sem tér ettöl nagyon el. Egy gyereknek, fiatalnak fel kell épiteni azt az életét, ami majd lesz, azokból az elemekböl, amik vannak. Magáról a szocializáció lélektani folyamatáról rengeteget tanultam ezektől az emberektől. Az ifjúságsegités identitásépités, meg az akadályok elháritása támogatása. Ott van szerepe az ifjúságsegitésnek - mint minden szakmának -, ahol baj van. Ha gyerek magától tud nöni, felnötté válni, akkor nincs rosszabb, mint amikor elkezdünk beleszólni a gyerekek életébe. Akkor van ránk szükség, amikor elakad. Nem biztos, hogy nekem meg kell mondanom, merre kell mennie. De az biztos, hogy segíteni kell megmászni az akadályt, megérteni és meghaladni azt, vagy már elöre látni... Ma eltartott kisujjal azt mondjuk: prevenció. Észre kell venni, hogy jöne a veszély! És van még egy: partner vagyok. Nagyon nagyok a generációk közötti különbségek, és nincsenek (vagy csak alig vannak) kapcsolatok. Nálunk még mindig müködik egy felülröl vezérelt mentalitás: idősebb vagyok, nekem többet kell tudnom. Például, amikor nyomdában dolgoztam, nagyon ritkán fordult elö, hogy egy fiatalabbtól segitséget kért volna egy idösebb kolléga. Az a fajta egyenrangú kapcsolat, ami sok-sok világban létezik, az nálunk egyszerüen nincs meg.

Hankiss Elemértöl, Csepeli Györgytöl a közösségekröl tanultam sokat, utóbbival és Ágh Attilával képzésekben is dolgoztunk együtt. Vercseg Ilika, Lörinc Judit - úgy hiszem - jó barátom is. Diósi Palitól is sokat tanultam. Lust Iván pszichiátertöl ${ }^{8}$ : „... egy fiatal ember ha magatartászavart, kommunikációs zavart vagy teljesitményzavart produkál iskolában vagy

\footnotetext{
7 A 70-es években a Kassák Klub vezetője volt, később generációk körében népszerü gyerekkönyvek szerzője.

${ }^{8}$ Lust Iván (1946-2006) 1982-töl vezette a Madarász Utcai Gyerekkórház pszichoterápiás-analitikus intézményét, a „Faludi utcát”.
} 
akárhol, az számomra feladat." Mondhatjuk, hogy semmi más dolga nincs az ifjúságsegítönek, ha egy gyereknél ezekböl egy megjelenik, vele már foglalkozni kell. Így kell azonositani a feladatot, ezekböl nem fegyelmi kérdést kell csinálni, ezek szakmai feladatok. Kovács Gyözö, a Neumann János Számítógép-tudományi Társaság vezetője a modernizációs ügyekben az egyik legjobb partnerem volt, amikor a Miniszterelnöki Hivatalban a távoktatási programmal próbálkoztam, annak ö volt az egyik ihletöje. Vekerdi Tamás, aki a Szinmüvészeti Föiskolán tanítva irt egy a részletekbe menö, igen alapos összehasonlitást a keleti és nyugati szinészmüvészetröl...

$*$

Kozák téren egyebek között romákkal is dolgoztam, müvészeti típusú programokkal. Most olvastam György Eszter tanulmányát, és engem is meglepett, hogy abból az időböl mennyi minden tovább élt. Cholival ${ }^{9}$ dolgoztam, de Péli Tamással és Lakatos Menyhérttel is gyakran találkoztam ott. Tamás például hihetetlen izgalmas müvészember volt, akinek a festményei csak egy részt jelentettek a müvészetéböl. Túláradó, gazdag fantáziájú, rendkivül okos fiatalember volt. Holland akadémián tanult festeni, gyönyörü festményei vannak, gyönyörüen írt, versei is nagyok jók. Bár Choli versei felül is irják azokat. Abban az idöszakban próbáltam én is felerösiteni a roma kultúrát. Az egy elevenen populáris kultúra, hogyan lehet abból fiatalokkal együtt is egy olyan identitást erösiteni, ami egyébként ebben a világban fontos. A mai helyzetben is ez a legnagyobb baj: attól, hogy a romák a kultúrájukat egyre inkább elengedik, vagy el kell, hogy engedjék. Lényegében az identitásukat is veszitik. Még azért vannak világok... Most majdnem csináltam egy rádiómüsort egy újpesti muzsikus cigány család fehér börü, gyönyörü szép lányával. Ö mondta, hogy beszólnak neki, hogy cigány. Kérdeztem töle, miben látja, miben különbözik a többiektöl. Igazában végül is nem tudta megmondani, hogy mi az, ami másokat zavarhat öbenne. Sokat dolgoztam a VIII. kerületben, és ma már talán én is meg tudom mondani, ki a roma, no, nem a börszín alapján, nem is a külsö után, hanem ahogy müködik. Ez a habitus valójában izgalmas és vállalható.

$*$

A 80-as években a zene egyfajta igazodási pont volt abban a szocializációs keretben, amiben felnötté váltak, amibe nem integrálódtak, az a világ nem volt számukra barátságos. Minden szembe ment a gyerekek várakozásaival, tulajdonképpen mindenben rosszul jártak. Kellettek nekik egyfajta identitást azonositó történetek. A szubkultúrának vannak látens kellékei, rengeteg rocker volt. Abban az értelemben volt szubkultúra, hogy valamivel szemben jelentkezett. Az ifjúsági kultúra ugyanúgy differenciált, ahogy a társadalom egészének a kultúrája. A rockzene például filozofikus zene, a szövegeknek súlya van. Amikor a gyerekek éneklik, az az ö azonosulásukat, valahová tartozásukat is jelenti. Bizonyos szempontból a biztonságukat. Ebben alapvetö életmentö szerep volt, ugyanakkor ez valamivel szemben jelentkezett. Abban az értelemben volt életmentö, hogy akinek nem volt ilyen igazodási pontja, annak a mentális állapota kritikus volt, hamarabb vitte el kábitószer, eröszak vagy más deviancia. Ilyen szempontból a rock meg is védte a gyerekeket. Rengeteg jól szituált tizenévest ismerek, akire nem figyeltek a családjukban, aztán megérte a rockéletet, majd visszament

${ }^{9}$ Choli Daróczi József (1939-2018) író, költő, müfordító 
decens úrikisasszonynak, fiatalúrnak, mert megkapta azt az igazodást a rocktól, amitöl nem fordult szembe a világgal, nem csinált hülyeségeket. Az egy külön történet, hogy az ifjúság hogyan engedi el az ifjúsági kultúrát és beépül, beszelídül, talál magának helyet a felnött világban. Valószinüleg azt a szerepet tölti be ez a zene és a sokfajta társas alakzat, amit l a felnött társadalom nem igazán tud. Nem segít társas eszközökkel szocializálódni. Sok oka lehet annak, hogy ezek a fiatalok tök egyedül maradtak volna, ha nem lett volna ez a világ.

Hogy a család mit csinál ezenközben, az is egy másik történet. Nagyon nehéz a családpedagógia. Idegbajt kapok attól, amit most gyerekjólétikben lehet látni. A családnak azt a funkcióját próbálják rontani segítés cimén, ami a legfontosabb, hogy el tudják engedni a gyerekeket. 16-17 éves korukban a gyerekeknek lassan már váltani kell, belül a szivükben. A családnak el kell engednie, hogy egy saját családot tudjon a gyerek alapitani. Ebben az értelemben két család közötti térségben vagyunk, amiben nagyon nem mindegy, mi történi a gyerekekkel. Amiben lehet átpártolás, sokféle folyamatról beszélhetünk, de alapvetö, hogy a családnak engedni kell. Nincs borzasztóbb, mint amikor a család 16 éves korban elkezdi nevelni a gyerekeit. Rengeteg ilyen ügyem van ma is, amikor a szülei a 16-17 éves gyereknek megmondják, hogy mit hogyan, miközben rá kellene már bízni a saját életét saját magára. Egy felnöttlét elsö lépéseiről van szó, szerencsétlenkedhet, még ügyetlen. De nincs már a szülönek az a szerepe, ami fiatalabb korban. A gyerekjólétik meg restaurálni akarják a gyerekekkel kapcsolatos történetekben a saját családjukat. Akkor szokott szembe kerülni a tizenéves a családjával, amikor a családdal különben is bajok vannak. Öregedik a mama meg a papa, fárad a kapcsolat. Belegondolnak, hogy mindjárt unokájuk lesz, és még nem is éltek. Konfliktusok is keletkeznek, a család megtartóképessége is sokkal gyöngébb. Jó a családsegítő megközelitése, amikor segíteni akar az anyának meg az apának, csak ne akarja visszaszoktatni, visszaszoritani a fiatalokat a gyerekkori családba. Nem is a gyerekeknek szoktam segiteni ilyen esetekben. 1617 éves korban már nem a szülöi családot kell felerösiteni, hanem azt, hogy milyen családot fog a gyerek létrehozni. A rossz családi mintáktól hogyan lehet megszabadulni, legalábbis mérsékelni a hatásukat, hogyan lehet felvenni jó mintákat.

A mamahotel másik történet. Nálunk nem az a szokás, hogy a gyerekeket 18 éves korukban elzavarják otthonról. Kényszerviszonyok és szokások miatt nálunk együtt élnek generációk, de a mamahotelhez még sok minden másra is szükség van. Ma az elkényeztetett gyerekeknél gyakran elöfordul az eröfeszités hiánya. A gyerek soha nem tanult meg eröfeszitést tenni azért, amit el akar érni. Miért várjuk el, hogy amikor 18 éves lesz, akkor hirtelen a kajával a szájába érkezik az eröfeszités? Meg kell tanulni dolgozni érte. A gyerekek nem tanulnak meg várni, hogy mondjak egy példát. Erőfeszitésekre van szükség, ha elsőre nem sikerül, akkor másodszor nekifogni. Ha a google-ban másodszorra nem találunk meg egy szót, azt mondjuk, nincs is ilyen.

$*$

Kortárs magyar ifjúsági munkán kellene-e változtatni? Kinek kellene változtatni? A fiatalok magukra vannak hagyva, - leginkább nem a középosztálybeli gyerekekröl beszélek, azok is magukra vannak hagyva, a látszat ellenére, hanem - úgy általában a magyar ifjúságról, tokkalvonóval. Szoktam erröl sokat beszélgetni. A Civil Rádióban például van most olyan ügyfelem, aki a Független Diákparlamentben és másutt aktív. Ügyfelemnek nevezem, mert nem tudom, minek nevezzem. A rádióban nem nevezem kliensemnek, meg ilyen szó nincs is, és rádiózni is 
szeretne, meg sok minden mást is szeretne, ezért mondom, hogy ügyfelem. Különösen sokat beszélgetünk, be szokott ülni a müsoraimba, végig hallgatja, egy rendkivül okos lány. Azt mondja, nem figyelnek rájuk. Kérdeztem töle: milyen szekciókban dolgozzák $k i$ az álláspontjaikat? Mi történik a javaslataikkal? Azt mondja, nem jutnak el néha a titkárságig sem. Válaszra sem méltatják öket, el vannak felejtve. De én azt gondolom, nem ök az igazán érdekesek. Mert aki tud érdeket képviselni az sokkal iskolázottabb, tudatosabb, sokféle szempontból jobb artikulációs bázissal rendelkezik. A gyerekek döntö többségének nincsenek szavai sem a helyzetére. A felnött társadalom nem várja öket munkával, iskolalehetöségekkel. Az a radikális rombolás, ami az elmúlt idöszakban történt, kultúrával, iskolával, egészségüggyel, az visszahat rájuk. Nem érzik jól magukat a börükben, ugyanakkor okosak és életrevalóak. Nem tudom, mit kéne velük kezdeni... Békén kellene öket hagyni. Ezektöl külön kellene választani az ifjúságsegités másik dimenzióját.

Azok a formációk, amik az elmúlt időkben megjelentek kisközösségi történetekként, azok azért nehézkesek, mert nincs hozzájuk rendelve egy csomó segítömozzanat, jól strukturált, támogató, nem megerőszakoló szakmai mozzanat, amit én ifjúságsegitőnek tudnék elképzelni. De ilyen szakma már nincsen. Az ifjúságsegités - nem mint a szociális munka, nehéz tüzérséggel támad a nehézségek helyrehozatalára, hanem - partnere a gyerekek kérdéseinek, elakadásainak, abban az értelemben, hogy megoldást keres: hogyan lehet továbblépni. Egy egészen más természetü segitó-támogató szerepre van szükség, ami nincs meg a mai világban. Ezért kellett volna az ifjúságsegítö szakma. Nem a szociális munkát korlátozom ezzel, hanem differenciálok. Ahogy van idösügyi projekt, az idösekkel is máshogy kell kommunikálni, a fiataloknak is más a világhoz való közeledése. Másként kell őket megerösiteni, máshogy kell visszajelezni. Ez hiányzik. Vastagon hiányzik a városi közösségi terekböl és a kistérségekböl is. Ott más módon kellene megjelennie a támogatásnak. Ennek nagyon jó formációi vannak az országban, mindegyikbe egy picit kellene besegiteni. Nógrádban láttam, meg Észak-Borsodban egy csomó kisérletet, hogy hogyan támogatják a gyerekeket. Ott nagyon ügyesek például. Azokról beszélek, akikre a legkevesebb figyelem van, akik nem akarnak érdekeket képviselni, csak élni akarnak, csak meg akarják találni a helyüket. Ezek kifejezetten szabadidös vagy szocializációs formációk, és nem lóg túl az érdeklödésük saját látóterükön, az utca végén. Sok ilyen formáció van tök egyedül.

Régebben is jártam az észak-magyarországi térségben, ismernek. Aztán dolgoztam a „Legyen jobb a gyermekeknek!” programban, a Ferge Zsuzsa vezette értékelö bizottságban. Aztán a maradványszervezet úgy döntött, hogy úgy tudja a kistérségeket segiteni, hogy megpróbálja az ott dolgozókat szakmailag megerösíteni. Mindenféle tartalmakra adtak képzéseket, csak speciel az ifjúságügyre nem nagyon. Aztán egy második, korrekciós körben megkértek engem, hogy dolgozzak ki egy programot, aztán, hogy valósitsam is meg. Hat-hét helyen lehettem és tehettem, és csináltam felkészitést, és így találkoztam ezzel a világgal, nagyon érdekes módon. A 2010-es évek elején volt ez, amikor még nem peregtek ki a korábbi szakemberek a programokból.

Nem tudom, hogyan kellene megváltoznia az ifjúsági munkának. Én már-azt hiszem-rábízom a következö generációra. A szakma maradványainak is lehetne találkoznia. De elöször is: igazi ifjúságügyhöz politikai akaratra lenne szükség. Arra a paradigmaváltásra, amit annyit 
mondtam már, hogy itt jön ki a könyökömön, amikor a hatalom nem a múlttal legitimálja magát, hanem a jövővel. Az ifjúságban jelenleg csak úgy gondolkodnak, hogy ök kitalálják a fiataloknak a jövöt. Annál borzasztóbb nincs, amikor egy mai 60-as életkorú kitalálja, hogy milyen legyen a fiatalok jövöje! Az a jövö az érdekes igazán, amit a gyerekeink maguk ki tudnak találni. Az ifjúság, az ifjúsággal való foglalkozás pozíciói rengeteget romlottak a rendszerváltás óta. A támogatások hiánya, a jogi szabályozás el nem végzése. Rengeteget beszélünk arról, hogy az ifjúsági törvény hiánya mi mindent jelent.

Az ifjúságügyben időnként megindult kampányok ott is rekedtek meg, ahol ezek az ügyek elmaradtak. Beengedték az ifjúsági igazgatásba, az önkormányzati bizottságokba, önkormányzati ifjúsági referensnek, a parlamenti bizottságba, a Mobilitásba a különbözö kultúrájú és iskolázottságú embereket, de nem adtak melléjük ifjúságsegitö szakmát. Azok a különbözö, más szakmai kompetenciák, amikkel beléptek az ifjúságügybe, mind deformálták azt. Nem integrálódott az ifjúságügy, hanem sokkal széttartóbbá vált, és sokkal esetlegesebb lett. A belépö emberek iskolázottsága, tapasztalata teljesen eklektikus volt. Hiányzott, hogy valakik mindezt rendezö szakmai elvekkel egységbe szervezzék. Amikor megindult az ifjúságsegitöképzés, akkor minden iskola mellé azokat a szakembereket lehetett aktivizálni, akik a környéken voltak. Így különbözö iskolák jöttek létre, az iskolákon irányzatokat is értve, melyek egészen másként gondolkodnak és dolgoznak. Nem volt akarat, hogy ezeket integrálja bárki is. És nem volt az sem, aki hiteles lett volna mint integrátor. Amikor mi a rendszerváltáskor a letéti számlás rendszerrel ${ }^{10}$ próbálkoztunk coomanagment-szisztémát kialakítani, akkortájt is csak az ifjúsági vagyon érdekelt mindenkit, a meglevö ifjúságügyi tudásbázis hasznositása senkit. A rendszerváltás környékén indult polgárosodás egyik fontos eleme az ifjúság volt, ami lehetöséget teremtett volna olyan törödésre az ifjúsággal, amiröl beszélek. Ez valamennyire a rendszerváltás után meg is indult. Helyi ifjúságkutatások alakultak ki. Diósi Palival arról beszélgettem a kezdetek idején egy rádiómüsoromban, hogy a helyi kutatásokat hogyan lehetne beépiteni a helyi ifjúsági programokba. Létrejött az ifjúsági igazgatás rendszere. Az elsö Fidesz-kormány is még ebben az ifjúsági típusú legitimációban gondolkodott, aztán a második Orbán-kormány már a múlt legitimációs eszközeihez nyúlt. Kormányzati szinten már korábban leértékelödött az ifjúságügy, de helyi szinten még volt lelkesedés, például amikor beindultak az ifjúságsegitö-képzések. Éhség volt a szakmára, például a csoportos segítés módszereire. A rendszerváltáskor a társadalmi folyamatokban levö akadályokat magyarázni próbálták. Nagyon aktív volt a társadalomkutatóknak meg a segitöknek a müködése.

Amikor én elkezdtem az ifjúságsegitö-képzésben tanitani, azt érzékeltem, hogy szakmával egyébként rendelkezö sok ember jelentkezett ifjúságsegitést tanulni. Azt a többletet keresték, ami az ö szakmájukon túl, a gyerekekkel való kooperációban azt erösítette volna fel, amit neki kellene csinálni. Keresték a gyerekekkel a kapcsolatot. Egy sokkal együttmüködöbb világot érzékeltem én a 90-es évek közepéig, végéig, amig nem radikalizálódtak a folyamatok. Azután a hatalomban ülők egyre bizalmatlanabbá váltak, például a civilekkel. Egyre inkább kivonták a forrásokat, egyre több szabályozást nem fejeztek be. Egyre inkább megjelent az a-szerintem - nem jó megközelítés, hogy a közszolgáltatások nyújtása egyre inkább állami monopóliummá vált. Ami azért volt bizarr a számomra, mert Ausztriában, az USA-ban mást tapasztaltam. Az

${ }^{10}$ Lásd sorozatunk Wootsch Péterrel megjelent interjúját! 
volt például egy koncepció, hogy a közszolgáltatásokra vannak standardok. Ha egy szolgáltatás kiállja a próbát, tökmindegy, hogy ezt egy kft hozta létre, egy egyház, egy sportegyesület vagy az állam, a közpénzt a szervezet megkaphatta. Ehelyett Magyarországon állami monopólium lett a közszolgáltatás, és a civilek minden mozgástere elfogyott, már a kábítószerszakma területén sincs elég civil szervezet.

Ma Magyarországon el kell dönteni, hogy kellenek-e a fiatalok. Ha igen, akkor ifjúságpolitikát kell csinálni, ami most olyan dermedt állapotban van, hogy nincs ifjúságpolitika a szó gyakorlati értelmében. Ha van ifjúságpolitika, stratégiában lehet gondolkodni, és azt aztán be is lehet árazni. Ha beáraztuk, akkor már minden a helyén van. Az igazgatást jelent, szakmát. A ma hatalomban ülö nem tudja, hogy van-e az ifjúsággal dolga. A fóvárosban 2009-ben ott tartottunk, hogy volt koncepció, abból program, ami már napirendre is volt tüzve, aztán levették. A föpolgármester-váltás után szó sem volt róla többet. Most a legújabb föpolgármester munkatársa kereste egy kolléganömet a tíz év elötti programot kérve. Barátaim biztatnak engem, hogy keressem fel az új föpolgármestert, de nem teszem, mert csapdába kerül, ha a föváros kezd ezzel foglalkozni. A kormányzatnak kell ifjúságpolitikát kezdeni, különben csak szimpla politikai ütközetek témájává válik, és csak rosszul jár vele mindenki. Drukkolok azoknak a pártoknak, amelyek beemelik az ifjúságot a programjukba, de ilyet egyet sem látok. Magyarországon még jelen van az ifjúsággal kapcsolatos összes szakmai alap. Ez a sok iskola, amiröl beszéltem, még mindegyikben ott vannak a szakemberek. Ezeket össze kellene hozni. Rengeteg feladat lenne azzal, hogy ezekböl lehessen letisztult dolog, de anélkül, hogy ezt valaki akarja, ez nem lehet. Ahogy telik az idö, ez egyre jobban kopik, és majd megint ki kell találni a kanálba a mélyedést.

A Pecsában 1x1,5 méteres volt az irodám. Középen volt egy kirakatos bolt, a belseje volt a kapocsosoké, a raktár volt az irodám. Úgy teremtettem intimitást a segitöbeszélgetésekhez, hogy a Pecsában beültünk középre, a sok ember kellös közepére. Ilyenkor tulajdonképpen békén hagytak. Amikor pedig valaki mégis közeledett, már lehetett mondani, hogy menjél innen. Meg lehetett rá számítani. Az hogy valaki bezárható helyiségben önállóan... ilyen népmese nincs! Csak most. A klinikai helyzetek szerencsére már sok helyen biztositottak, de akkor az volt a klinika. Ott tanultam meg, hogy a közösségi típusú ifjúsági munka soha nem falakat jelent. Falakat sose jelent. Mert ha falakat jelentett volna, rég nem lett volna Kapocs. 70-80 ember tartozott a Kapocshoz. Nem lehetett arról beszélni, hogy mindenkit behívok oda, és velük dolgozom. Valamelyik lánynak volt egy szélsőjobbos pasija, fehér cipöfüzös. (Ez deklarált jele volt a rasszista gondolkodású fiataloknak.) És a srácok azt mondták neki, hogy hoppá! És ahelyett, hogy elküldték volna, behívták, és volt egy állati nagy beszélgetés. Hogy össze kellene a dolgokat hasonlitani. Hogy amit a lány csinál, és ahogy gondolkozik a fickó, mekkora a különbség. Akkor miért segítettél annak, meg annak, ha rájuk azt lehetett volna mondani, hogy az egy büdös cigány? Nem zavarták el, de legközelebb már nem jött a lány fehér cipöfüzövel, és két-három hét múlva már nem volt a fiú a környezetében. Elérték a srácok. Én nem tudom azt a beszélgetést visszaidézni, de megmutatta, hogy lehet az összes elöitéletes, eröszakos ronda dologgal bánni, ha partnerek abban a fiatalok. Nem engedték el, mert fontos volt nekik a lány, ugyanakkor abszolút kökemények voltak azokban a normákban, amik számukra fontosak voltak. 
Amikor érkeztünk a Petöfi Csarnokba, akkor az nagyon eleven volt. Heti három-négy koncertet tartottak, nem csak szombat-vasárnap, hanem szinte folyamatosan. A célközönség nagyon sokféle volt. És nagyon érdekes koncepciót irt le Diósi Pali. A Petöfi Csarnoknak évente félmillió látogatója van, és ezeknek a fiataloknak a felnötté válása nem megy magától. Egy csomó olyan problémával küzdenek, amire a Pecsa önmagában nem tud választ adni. Ezek a problémák bejönnek az ajtón. Mindenféle eröszak van, mindenféle változatban, kell valamit csinálni, és erre kellett nekem egy koncepciót beadnom. Ezzel kezdödött az egész. Tölem azt várták el, hogy ezekkel a gyerekekkel valamit csináljak.

Én is valószinüsitettem egyébként, hogy milyen problémái voltak a fiataloknak, de fontos volt, hogy ök mit mondanak, és milyen sorrendet alakitanak ki a problémák között. 400 föt kérdeztek meg ${ }^{11}$. És a kérdöiv egy ponton tartalmazta, hogy amennyiben a válaszadó tenne azért, hogy jobb legyen a helyzet, megadhatta zárt boritékban az elérhetöségeit. Kaptam 40 boritékot. Ezzel indult a Kapocs: mind a 40 boriték gazdáját meghívtam egy napra '92 októberében beszélgetni. Abból a 40 fiatalból eljött 23. Beszélgettünk, és abból indult a Kapocs. Egy sajátélményszerü dolgot kezdtem. Beszélgettünk, hogy ök hogy vannak, és milyen ez a világ, és kerestünk egy csomó közös pontot, hogy mi közünk van nekünk egymáshoz. És ezek között volt egy csomó dolog, amit mi is tudtunk orvosolni, és így jött létre a Kapocs, a velük való szövetség. Kötöttünk egy szövetséget, hogy nem hagyjuk igy, és nem hagyjuk magunkat. És onnantól kezdve hívták a barátaikat, a barátaik a barátaikat, és úgy épült a Kapocs a legelején, hogy egymásnak átadták a normákat, és nekem nagyon könnyü dolgom volt. Nagyjából aztán addig volt könnyü dolgom, amíg a magyar társadalom is erösödött. Amikor radikalizálódott a politika, meg a társadalom, megjelentek a különbözö radikális szervezetek bal- és jobboldalon, az a mikrovilágra nagyon durván hatott. A mikrovilágban sokkal több a védtelen, mint az, aki meg tudná magát védeni. Nagyon sok vesztes jelentkezett, megnött a feszültség. A Kapocsban érzékelhetöen megerösödött a feszültség. És megjelent egy cinikus kultúra, aminek a kifejezése volt az „,ij”. Így járt. Ennél borzasztóbb és cinikusabb megközelítést keveset tudok. Pont abban a világban, amelyikben az emberek segitségre szorulnak, segítségre kényszerülnek, a cinikus megközelítésnél nincs elidegenitőbb és sértőbb. Ez nagyjából 94-96 körül jött elö. Akkor volt az első válság a Kapocsban, pontosan ez miatt. Meg kellett újítani. Minden csoportfolyamatnak a dinamikáját érteni kell. Nagyon sokat tanultam csoportlélektant, és alapvetönek tartanám, hogy sokkal többet kellene tanitani. És itt tanultam meg, hogyan lehet továbblépni egy ilyen látható krízisen.

Az ismeretek megszerzésének ma már nem az iskola a kizárólagos helye. Az ismeretek a gyerekek számára nagyon is hozzáférhetöek, de nagyon esetlegesek, nagyon összevissza vannak. Ezeknek az ismereteknek a rendszerezésében, rendszerbe foglalásában bizonyos szempontból kicsit müvezetöszerübb, animátori szerepe van a pedagógusnak, ami nem arról szól, hogy ö adja a tudást, hanem segitenie kell lefordítani, és ebben az összes cselekvő módszer nagyon izgalmas. Amikor nem arról van szó, hogy mellé tanulunk az egyik könyvhöz a másikból, hanem rápróbáljuk valamire. Abban kell segitenie a tanárnak, hogy az összevethetö tudásokat össze tudják vetni a gyerekek, össze is vessék. A tanulás kritikai munka is, hogy meg tudjam

11 Diósi Pál Kinek ígéret, kinek délibáb A Petőfi Csarnok látogatói nemzedékükről és önmagukról Család, Gyermek, ifjúság 1992/3-4 https://epa.oszk.hu/03400/03457/00003/pdf/EPA03457_csalad_1992_03-04_050066.pdf és 1993/1-2 https://epa.oszk.hu/03400/03457/00004/pdf/EPA03457_csalad_1993_01-02_079-085.pdf. 
mondani, hogy melyiket tartom odavalónak és melyiket nem, melyik tudás illeszkedik az egészbe és melyik megy szembe vele. Például irodalomban vagy történelemben nem egzakt dolgokat tanulunk, hogy miként láthatjuk, mi a lényeges és mi a lényegtelen, csak ütköztetéssel lehet.

Az elsö vizsgálat után 4 vagy 5 évvel felkértük Diósi Palit egy második vizsgálatra, ahogy sikerült rá pénzt összeraknom. Ugyanúgy problémafeltáró vizsgálat volt.

A Kapocsot lehetett tagsági viszonyon alapuló szervezetnek tekinteni, meg nem is. Rengeteg felületünk volt, amiben együtt kellett dolgozni, például rengeteg esetmegbeszélésünk volt. A tevékenységeink nem voltak közösek, mindenki a saját társas közegében végezte a segítömunkát. Maguk helyezték üzembe magukat és segitettek. És voltak eseménylapok, amikkel a segitségnyújtásokat rögzitettük. Mindenki a maga világában segített, és nem is vártam el, hogy ezek egymás mellé rakhatóak legyenek. A Moszkva tér fölötti üregekben meghúzódó kábítószerfüggők ellátását nem kevertem össze a szerelmi válságban levö középiskolásoknak a konfliktusaival, amikor arról volt szó, hogy a barátját elhagyta az ö barátnője. És akkor elment a barátjával a McDonald'sba, és a világ legnagyobb lelkisegély-programját valósitotta meg, mert a bánatos fizette a mekit, ö pedig megbeszélte vele a lelki problémákat. Ez azért volt jó, mert ez egyébként nem komoly, nem kifejezetten szakszerü dolog, de ha ez elmarad, akkor kellhet pszichológus. Fontosabb ifjúságsegitö munkát nem tudok elképzelni, mint hogy valaki nem hagyja magára a barátját, és megbeszélik a dolgokat. Igazolványa volt mindenkinek, ami feljogositotta, hogy a Pecsában rendezvényen részt vegyen, de ez funkcionális volt. A Kapocs sosem volt közösség a szó eredeti értelmében. Közösségi volt. Az azt jelentette - ez óriási különbség! -, hogy mindenkinek volt a saját baráti környezete - és azzal ö érkezhetett a Kapocsba -, de nem vehette át az uralmat! Ez azt jelentette, hogy mások társas kapcsolatai, ügyei legalább olyan fontosak voltak, mint az övé. Egymást kizáró kulturális felfogású gyerekek is tartoztak a Kapocsba, és egyiknek sem engedtem elönyt. Hogy mondjak analógiát: az ifjúsági klubok jelentös részénél azt mondjuk, hogy közösség, és másokkal szemben szoktuk megvédeni ezt a közösséget. Ahelyett, hogy azt mondanánk, hogy a szomszéd utca gyerekei is hozzánk tartoznak, ök ugyanolyan fontosak. Amikor megjönnek a másik utca gyerekei, akkor velük foglalkozom, ha a fene megeszi is azokat, akik elöbb érkeztek, de rájönnek arra, hogy ha ott akarnak lenni, akkor másokat is tolerálniuk kell. Ebben az értelemben válik a dolog közösségivé. A VIII. kerületi cigány gyerekek mindig fürödtek, spray, minden megvolt. Egyszer aztán ózdi cigány gyerekek költöztek a környékre, akik, mint a rockerek, hetente ha kétszer fürödtek. Azt mondták rájuk a józsefvárosiak: ezek a büdös cigányok. Mondtam nekik, nekem ök ugyanolyan fontosak, és pöpec srácok, higgyétek el nekem! Nem engedtem, hogy háború legyen. Magyarul a közösségi azt jelenti, hogy mindenki a saját közösségében legyen teljesebb, sikeresebb. Teljesebb, attól, hogy egyrészt segít a többieknek, másrészt megtanulja a válaszokat. A társadalmi problémákat általában tudjuk azonositani, de a válaszokat kevésbé. Az, hogy ö segitö szerepet vállal, mindenképpen pozitív problémaorientáltság. Neki megoldásokban kell gondolkodnia, ha segiteni akar, ami a saját életére visszahat. Az egész segitö munkánk arra kondicionált mindenkit, hogy megoldásközpontú legyen. Ez elkísérte őket mindmáig. Most is hallom a történeteiket, és nagyon büszke vagyok rájuk, megmondom öszintén. Saját helyzeteiket meg tudják oldani, nem várják, hogy majd jön a válasz. 
Az egykori kapocsosok egy része csinált saját közösséget, más része nem, de mindenki kitalálta a maga szerepét. És persze van, aki megrekedt, úgy állt meg, ahogy elhagyta a Kapocsot. Nincs egy tipikus kapocsos utóélet. Nem vártam el senkitöl, hogy szakember legyen. De azért lettek. Például Kovács Edit, a Közösségfejlesztők Egyesülete vezetője. Fehérvári Szilvia a XI. kerületi tanodát szervezte és müködtette. Még kapocsosként volt Spanyolországban egy ifjúsági találkozón. Én sose mentem a Kapocs képviseletében külföldre. Szilvi ezen a találkozón megismerkedett egy belga fiúval, aki élt is itt egy darabig, és most a gyerekei apja. Belgiumban élnek.

$*$

A Kapoccsal kezdtem a Civil Rádióban a rádiózást, mert a gyerekeknek, akik oda jártak, nem voltak meg az eszközeik a saját problémáik artikulálására, a gyerekeknek kevés szavuk van a bajuk, problémájuk elmondására. Azt régóta tudom, hogy az emberek nem tudják elmondani a bajukat, és ebben jobbnak kellene lenni. Mert a baj sokkal a tudat alatt vagy elött van. Amikor valakinek meghallgatod a baját, tudnod kell, hogy mindent úgysem fog tudni elmondani. Mindenképpen többet kell elmondani, és az volt a feladat, hogy megtanuljanak a gyerekek beszélni. Kérdezni is, meg mondani is. Erre a legalkalmasabb volt a Civil Rádió. Már a próbamüsorba beleraktuk a gyerekeket. Minden második héten azok a lelkes, de rosszul kommunikáló gyerekek mentek a Civil Rádióba müsort csinálni. Készültünk is. Nem a müsor volt az érdekes, hanem az, ahogy készültünk. Beszélgettünk. Kerestük a témákat. Fontos, soha meg nem oldható kérdésekröl beszélgettünk, mint hogy lehet lányok és fiúk között barátság. Most újra indítottam egy ilyen ifjúsági csoportot, és arról beszélgettünk a legutóbbi adásban, hogy átok vagy áldás-e a mobiltelefon. A jövö héten az iskolai terhelésröl fogunk beszélgetni. Napirenden az oktatás felháboritó felkavarása. Arról fogunk beszélgetni, hogyan viselik ök a terheiket. Volt egy sorozatom arról, hogy lehet-e jó iskolát csinálni, abban volt egy adás egy kilencedikes kislánnyal. A Civil Rádió nekem így indult, hogy megtanultak a gyerekek kommunikálni. És aztán volt a Kapocs Kortárssegitő Magazin, amit a kortárssegítők csináltak maguknak, és ez tartott vagy 300 adáson át.

Amikor a Petöfi Csarnokból átmentünk a VIII. kerületbe, nagyjából a csapat is megszünt. A VIII. kerületi gyerekekböl is csináltam egy csapatot, és hoztam a Civil Rádióba. Olyan cigány gyerekek voltak, hogy valahogy mindenkit zavartak. Én ugyan kedveltem öket. Tök arik voltak, de ahogy könnyedén, lazán mozogtak és mindenhez hozzányúltak, az a fajta - talán több, mint természetes - müködésük baromira irritáló volt sok más embernek. Nekem nem. De ott mindenki tartott tölük. Mint ahogy felszálltak a villamosra, és jelen voltak. És ha látták, hogy imponáló, vagy valakinek az idegeit sértö, akkor tetszett nekik, és rátettek még egy lapáttal. Úgy kellett döntenem, hogy a Civil Rádióban egy új müsort indítok, ez már Ifjúságsegítő Magazin, és szakmai, és a gyerekekkel való beszélgetést meg átvittem a Rádió C-be. Ott is rádióztam, amíg volt a Rádió C. Csináltam nekik reggeli müsort, és a cigány gyerekekkel ott beszélgettünk, például hogy lehetséges-e barátság lányok és fiúk között. Meg természetesen másról is.

Lehetne a rádiózás az ifjúsági munkának olyan eszköze, mint a dráma. Most az én müsoromon kivül nem nagyon tudok rádióban ifjúsági tárgyú müsort. Amikor elinditottam a müsoromat, az állami rádióban és tévében volt még ifjúsági müsor. Most már nincs. Ráadásul az én müsorom ifjúságszakmai, csak nem olyan módon, ahogy az ifjúsági szakma szereti. Gyakran voltam 
sokkal kritikaibb. Nagyon sok szociális, kábitószeres, cigányos témát csinálok, ami nem sajátja az ifjúságsegítö szakmának. Amibe ök nem szoktak belemenni, én abba belementem. Rájöttem arra, hogy a rádió egy ideig a munkámat segítette, aztán meg ... Ritók Nóra szavait hozom vendégül, aki azt mondta, hogy láttatni kell. Amit látunk, azt el kell mondanunk. Az a feladatunk. És ezt csinálja is Ritók Nóra. És igaza van. És én haragszom azokra az emberekre, akiknek van tapasztalata, és csendben vannak, mert sok az ugató, sok a mellébeszélö. Sok hamis hang van. Akkor az fog beszélni, aki az Észbontóban szerepel. A szakembernek el kell mondania, amit gondol. Az a feladata. Nem csak csinálni kell, el kell mondani. És ezt csinálom én is, hogy elmondom, elmondatom a vendégeimmel. Sokat foglalkoztunk az iskolarendszerrel, a szegénységgel, a kábitószerüggyel, eröszakkal, prostikkal, menekültekkel. Sok olyan témával, ami kiveri a biztositékot. Nálam ültek bent csadorban meg hidzsábban muszlim lányok, és beszélgettünk a szerelemröl, hogy van-e náluk individuális szerelem, mint Európában, mint nyugaton. Azt mondták, lehet Rómeó és Júlia, ha egyébként el tudja tartani a családját, és buzgó muszlim. Ha ezt a kettöt nem tudja, szó sincs individualizmusról.

A Civil Rádió rengeteg müsora elszáll, nem archiválódik. Mindig nagyon mostoha körülmények között dolgoztunk. Tavaly decemberben fosztottak meg bennünket a frekvenciától. Mindenféle szempontból csak kivetni valókat tudok mondani erröl a döntésröl. Nyilván pereljük. Most már csak az interneten vagyunk, de ettöl még a feltételeink szörnyüek. Alig tudjuk betölteni azokat a szerepeket, amiket felvállaltunk, mert támogatás sincsen nagyon, mert a Civil Rádió nem állt be semmilyen politika, semmilyen támogató mögé. Egyszerüen nem akartunk. A Civil Rádióban egyszerre jelen van a mai kormánynak rajongója is, de van véresszájú a másik oldalról is. Nem engednénk be a pártpolitikát, meg az egyházakat és a pasztorációt sem. Mert a hitek, meg a vallások beleférnek, de az egyházaknak vannak müsoraik.

865. müsoromat raktam össze, annak a fele nem érdekes. Diósi Pali, Kátai Gábor és ilyen müsoraim vannak. Örzöm is öket, mint hímes tojást. A gondolataik érdekesek. Beszélgettem másokkal is. Szükség van ezekre a dolgokra. Olyan felelötlenül müködik a világ ebben az értelemben is. Gábor hihetetlenül nagy veszteség. A szakmának is. Emberileg alapvetö. Megvolt a maga nézete az ifjúság ügyében, de nagyon kompromisszumkész és egyénien integráló típus volt. Nagyon sok funkciója van a rádiónak. Zürichben a prostinegyedben van egy nagyon nagy magyar jelenlét. Arról csináltam egy müsort, amit még keresek, mert azt is fel akarom tenni. Abból szakdolgozatot is írt valaki. Aztán jóval később jelent meg a témáról a Viktória címü film. A rendör Németh Zsolttal készitett müsort a napokban találtam meg 2011-böl, mára érvényes mondatokkal. A Wootsch Péterrel 2019 végén készitett müsort is felraktam. Az utóbbi müsorok közül ennek volt az egyik legnagyobb visszhangja. Gyarmathy Éva pszichológus is nagyon okosakat mondott az iskoláról. Azért mentem rádiózni, mert én sem tudok jól kommunikálni. Sok dolgot nem tudok megfogalmazni, a rádió segített egy kicsit. Lassan már fáradok, és le fogom tenni a lantot.

Dolgozom. A Civil Rádióban jelenleg vezethetem a szerkesztöbizottságot, amit különben a hátam közepére sem kívánok. Van egy müsorom minden második pénteken, a 117 perc. Kétórás magazinmüsor, kökemény és nagyon izgalmas. És minden kedden van a Kapocs Ifjúságsegitö Magazin. Mellette egy rendelöben dolgozom még. Coach és tanácsadó vagyok, és egyéni problémákban segitek. Jönnek szülök, gyerekek, felnött emberek. Coach vagyok, mert 
elvégeztem az alapfokú coach-képzést. Azt megkockáztatom, hogy ifjúsági szakértőnek nevezzem magam 42 év után. Ez van a honlapon rólam. Ma hívott egy apuka, hogy a 17 éves fiával nem tud mit kezdeni, kér tölem egy időpontot. Ez nekem a profilom, én ezeket szeretem, ez a kedvenc témám. Úgy gondolta, hogy én majd a fiát fogadom. Általában ezt szokták gondolni: födarab-csere a gyereknél. De én a gyerekeket kényszerböl sohasem fogadom, akiket hozzám parancsolnak. Annak nem lehet segiteni, aki nem kéri a segitséget. Mindig annak kell segíteni, aki kéri a segitséget. Ez a szakmai alap. Apuka kért tölem segítséget, akkor neki kell segíteni. Hiába gondolja, hogy a fiának kell segíteni, neki kell segítség.

Sok ügyfelem van, velük beszélgetek, ezt csinálom másfél napon egy héten. Elég terhes, fárasztó. Felkészülök, feldolgozom, naplózom. Nem pszichológust játszom, nem is vagyok az. Nekem a változás a feladatom és a cselekvés. A cselekvés, a lebénulás helyzetében kell tudni partnernek lenni. Más összefüggésben már emlitettem, hogy a gyerek sohasem tanulta meg az eröfeszitést, amit pici korban kell megtanulni. És pici korban kell jól reagálni a gyerekre. És jól kell visszajelezni a gyereknek. Nincs borzasztóbb, mint amikor az apuka kimegy a homokozóba a gyerekkel, és felépitik a várat, hazamennek és azt mondja az apuka, hogy ,felépitettünk” egy várat, miközben a gyereke nem fért hozzá, az apja nem is engedte. Hamis énképeket alakitanak ki ezek a gyereknevelési módszerek.

Meg kell tanulni a gyereket jól dicsérni, ha jól csinálja. Meg kell tanulni például, hogy a pályaválasztás 4-5 éves korban van. A pályaválasztási tanácsadás azért 3-4-5 éves korban, mert akkor kell a gyerekek képességeit észrevenni. És a szülönek dicsérni és baromi sokat dicsérni, ha jól csinálja, és láthatóan jól érzi magát benne. Mert ebböl lesz aztán az álom. Az álomból lesz a cél, s a célból a feladat. Én láttam tehetséges gyerekeket. Találkoztam Csermely Péter csoportjában olyan gyerekekkel, akikhez külföldröl hívtak professzort, mert a magyar professzorokat már elfogyasztották. Amikor elmentem hozzájuk beszélgetni, az érdekelt engem, hogy ök miben mások. Rájöttem, hogy semmi különbség, ugyanolyan maflák, mint mi. Elrontják az életüket, rosszul beszélnek, nagyon sok dologban hasonlitanak ránk. Két dologban szerintem nagyon különbözöek, mint mi vagyunk. Egyrészt tudják, hogy miröl szól az életük, mindenkinek megvan a mániája. Másrészt pokoli jól tudnak figyelni. Azt gondolom, a figyelés képessége, hogy észrevesz valamit, adja meg a lehetöséget a különbségtételre. Aki nem vesz észre különbséget, az nem tud azon gondolkodni sem. A figyelem képessége hihetetlenül fontos. Szeretnék három-négy éves lenni, mert ök naponta tanulnak ezer meg ezer szót, fejük mint a szivacs szivja magába a dolgokat. A tanulás képességéért hihetetlen irigy vagyok.

Másrészt úgy érzem, hogy írnom kell. Le kell írnom a Kapocs szakmai módszereit. Nagyon fontos lenne leirni. Néha még szoktam képezni, tehát módszereket tanitani. Alapvetö módszereink vannak, amiket máshol nem lehet nagyon tanulni. Ha ez szakmává válik, akkor tudok felelösséget is vállalni. A mi munkánkban, a Kapocs szintjén, nincs rá mód, hogy anamnézisünk legyen. Alig van rá lehetöség, hogy a megérkező problémás gyerek esettörténetét össze tudjuk szedni. De válaszolnunk kell és segíteni. Abban a helyzetben meg kell tanulni valahogy jobban tájékozódni azokkal az eszközeinkkel, amik vannak. Hogyan lehet rövid idö alatt, rövid találkozásokból válaszképessé tenni magunkat. Nyilván ez nem egy mély szakmai dolog. Nyilván nem arról szól, hogy valaki analitikus mélységekig tudjon egy lelki problémát feldolgozni, de azt, hogy mi a probléma és hogyan lehet továbblépni, azt meg kell látni. Lehet, 
az a továbblépés, hogy meg kell majd nézni a hátterét, lehet, a továbblépés egy új kapcsolat. Tehát a Kapocs olyan módszerrel dolgozott, ami mostoha találkozási viszonyokban válaszképes volt. Müködött és látom, hogy a volt kapocsosok a munkahelyükön talán ma is alkalmazzák. Gyorsabban tudnak eligazodni, gyorsabban tudják, mit kell mondani. A képzésnek része, hogy frame-ekkel vagy forgatókönyvekkel dolgoznak az emberek, és ha ezt tudatosítjuk, akkor tudjuk, hogy a mintába ne ragadjunk bele. A minta azonositásra alkalmas eszköz, segít a profilt kitalálni. A változás nem a mintáról szól, hanem az adott ember diszpozíciójáról, hogy mit kell csinálni. Az is lehet, hogy többfajta minta van, és a minták disszonanciájáról van szó. A papa meg a mama mintája a gyerek napi müködésében találkoznak konfliktusként. Lehet, nem tudják, hogy különbözö mintákat tanítanak, ami a gyerek számára alkalmazkodási terhet jelent. Tanuljuk a rendszerközi akkomodációt is. Sokfajta értékrendszer, szisztéma van a világban. Az egy többletképesség, hogy valaki ezek között át tud járni, tudja, hogy kell beszélni a szakáccsal, a rendörrel és az anyjával. Tud különbséget tenni normák között, ez a különbözöségnek való megfelelés képessége. Sok gyerek be van zárva egy értékrendszerbe, nincs lehetösége megélni másik mintát. Amikor a gyerekekkel baj van, gyakran öket hibáztatjuk, pedig lehet, hogy a szocializációjukból hiányzik ennek a képességnek a kialakitása, hogy tudjon közlekedni rendszerek között. Magyarul, nem normális, hogy egy gyerek nekimegy a rendörnek. Ha végiggondolja, a rendör lesz az erösebb. Amikor tanulunk felnötté válni, pontosan tudjuk, hol a határ. A problémás gyerekek nagy részének, akikkel találkozom, fontos tünete ennek a képességnek a hiánya. Ezzel ö lesz megtéve föszereplönek, mondván nem tud alkalmazkodni, pedig dehogy nem tud alkalmazkodni! Különbséget tenni nem tud!

Kapocs ma már gyakorlatilag nincs, csak Kapocs-program a Jövöbarát Egyesületben. A III. kerületbe átkerülve 2016-ban persze egy rövid ideig volt még lendület is bennünk. Aztán az is elfogyott, és ma már esélyünk sincs arra, hogy meg tudjuk csinálni azt, amit korábban a Petöfi Csarnokban vagy a VIII. kerületben. De ma már a közeg sem fogadó kész."

Budapest, 2019 október-2020. március

Az interjút készítette és szerkesztette: Tóbiás László 